\title{
The c-ros tyrosine kinase receptor controls regionalization and differentiation of epithelial cells in the epididymis
}

\author{
Eva Sonnenberg-Riethmacher, Barbara Walter, Dieter Riethmacher, Stephanie Gödecke, and \\ Carmen Birchmeier ${ }^{1}$
}

Max-Delbrück-Centrum (MDC) für Molekulare Medizin, 13122 Berlin, Germany

The c-ros gene was originally identified in mutant form as an oncogene. The proto-oncogene encodes a tyrosine kinase receptor that is expressed in a small number of epithelial cell types, including those of the epididymis. Targeted mutations of c-ros in the mouse reveal an essential role of the gene in male fertility. Male c-ros - / - animals do not reproduce, whereas the fertility of female animals is not affected. We demonstrate that c-ros is not required in a cell autonomous manner for male germ cell development or function. The gene, therefore, does not affect sperm generation or function in a direct manner. The primary defect in the mutant animals was located in the epididymis, showing that c-ros controls appropriate development of the epithelia, particularly regionalization and terminal differentiation. The epididymal defect does not interfere with production or storage of sperm but, rather, with sperm maturation and the ability of sperm to fertilize in vivo. Interestingly, sperm isolated from c-ros - / - animals can fertilize in vitro. Our results highlight the essential role of the epididymis in male fertility and demonstrate a highly specific function of the c-ros receptor tyrosine kinase during development of distinct epithelial cells.

[Key Words: c-ros tyrosine kinase receptor; epithelial cells; epididymis; regionalization; terminal differentiation]

Received February 5, 1996; revised version accepted April 3, 1996

Tyrosine kinase receptors and their specific ligands can have essential roles during embryonic development and adult physiology. Receptors and ligands often form paracrine signaling systems, therefore providing a molecular basis for the interaction between different cell types. Such interactions are essential for ordered growth, differentiation, and morphogenesis in development and can critically influence homeostasis /Geissler et al. 1988; Dumont et al. 1994; Wang et al. 1994; Bladt et al. 1995; Meyer and Birchmeier 1995; Miettinen et al. 1995; Sato et al. 1995; Schmidt et al. 1995; Sibilia and Wagner 1995; Threadgill et al. 1995). The importance of these molecules is also emphasized by the fact that many genes encoding receptor tyrosine kinases were originally identified as oncogenes (Yamamoto et al. 1983; Hampe et al. 1984; Bargmann et al. 1986; Besmer et al. 1986; Martin et al. 1986; Takahashi and Cooper 1987), among them ros. Two independent isolates of transforming ros genes were characterized, the oncogene in the chick retrovirus UR2 and a human isolate identified in a transfection tumorigenicity assay (Neckameyer and Wang 1985;

${ }^{1}$ Corresponding author.
Birchmeier et al. 1986). Both oncogenes encode truncated proteins that lack a c-Ros-specific extracellular domain. The proto-oncogene encodes an "orphan" receptor-type tyrosine kinase (Birchmeier et al. 1990; Matsushime and Shibuya 1990; Chen et al. 1991; Riethmacher et al. 1994); the c-ros-specific ligand is as yet unknown. The receptor is expressed in few epithelia, among them the Wolffian duct and some of its derivatives (Sonnenberg et al. 1991; Tessarollo et al. 1992; Chen et al. 1994).

The epididymis develops from the Wolffian duct in the male and functions in sperm maturation and storage. It consists basically of a convoluted tubular epithelium that connects the testis to the vas deferens. During passage through the epididymis, the spermatozoa undergo various morphological and functional changes that result in their competence for fertilization (Bedford 1975; Cooper 1995). These include the ability to move, to undergo the acrosome reaction, and to penetrate the zona pellucida. A high percentage of male infertility in humans was suggested to originate in the malfunction of the epididymis (Lunde et al. 1990).

Anatomically, the epididymis can be subdivided into the proximal caput, the middle corpus, and the distal 
cauda. Epithelia of different parts are characterized by distinct morphologies and have different functions /Sun and Flickinger 1979; Dacheux and Paquignon 1980; Robaire and Viger 1995). Initially, the entire epididymal epithelium has a homogeneous appearance. During puberty it undergoes terminal differentiation, forming columnar epithelia that display region-specific features, for instance, gradients in height (Sun and Flickinger 1979). Region-specific differentiation of the epididymis is also reflected in differential expression of various genes or enzyme activities, for example, proenkephalin, c-raf (Douglass et al. 1991; Winer et al. 1993) or $\beta$-galactosidase. Regionalization of initially uniform structures is an inherent theme of development and occurs during differentiation of the endoderm, brain, or heart. In Drosophila, a signal that determines regionalization of the egg is given by torso, a tyrosine kinase receptor (Lu et al. 1993; Savant and Montell 1993).

We have generated targeted mutations of the c-ros gene by homologous recombination in embryonic stem (ES) cells that were used to generate mice carrying the mutation. Animals with homozygous mutation in c-ros are viable and healthy. However, ros $-/-$ males are infertile, the consequence of a primary defect in epididymal regionalization and differentiation. Our results highlight the role of the epididymis in male fertility and provide evidence for the essential function of c-ros in the control of epithelial differentiation.

\section{Results}

Generation of ES cells and mice carrying a mutant c-ros gene

Two different targeting vectors were constructed (Fig. 1), which allowed the introduction of the mutation into c-ros sequences that encode the extracellular domain $\left(r o s^{e x}\right.$ allele) or the protein kinase domain (ros ${ }^{k i n}$ allele). In addition to genomic c-ros DNA, both targeting vectors carried neo-resistance (neo) and herpes simplex virus thymidine kinase $(t k)$ genes as positive and negative selection markers, respectively (Mansour et al. 1988). The vectors were introduced by electroporation into E14-1 ES cells (Kühn et al. 1991); selection with G418 and Gancyclovir was used to enrich for homologous recombination events, which were identified by PCR. PCR-positive clones were analyzed by Southern blot hybridization to verify that a single integration event had taken place by homologous recombination (Fig. 2a,b; data not shown). A neo cassette was inserted in an extracellular exon to generate the rosex allele; the neo cassette also introduces termination codons in all three reading frames. Two exons that encode sequences of the tyrosine kinase domain are deleted in the ros ${ }^{k i n}$ allele and replaced by the neo cassette. Six independent ES-cell clones, three for each mutant allele, were injected into blastocysts. Four EScell clones, two containing the ros ${ }^{e x}$ and two the ros ${ }^{k i n}$ allele, produced germ-line chimeras that were used to establish strains that carry the mutation. Matings of heterozygous mice gave rise to $25 \%$ of homozygous mutant animals. Similar numbers were observed for animals that carried ros ${ }^{e x}$ or $\operatorname{ros}^{k i n}$ (Table 1A).

Western analysis of c-ros was performed using antibodies against a carboxy-terminal peptide (Riethmacher et al. 1994). The c-Ros protein was found to be expressed in adult epididymides (Fig. 2d; see also below). No c-Ros protein was detected in epididymal extracts of homozygous mutant animals, regardless of whether they carried ros $^{e x}$ or $\operatorname{ros}^{k i n}$ alleles (Fig. 2c). In addition, ros-specific transcripts were analyzed by Northern analysis in animals that carried the $\operatorname{ros}^{e x}$ allele. The c-ros transcript from wild-type $(+1+)$ animals was $8.0 \mathrm{~kb}$ in size. In homozygous mutant animals, two mRNA species were detected with a cDNA probe that encodes extracellular c-ros sequences: (1) A 4.4-kb mRNA corresponding to a fusion transcript containing extracellular coding sequences of c-ros and the neo cassette; this transcript ends at a poly (A) site present in the neo cassette; (2) a 9.2-kb mRNA corresponding to a fusion transcript con-

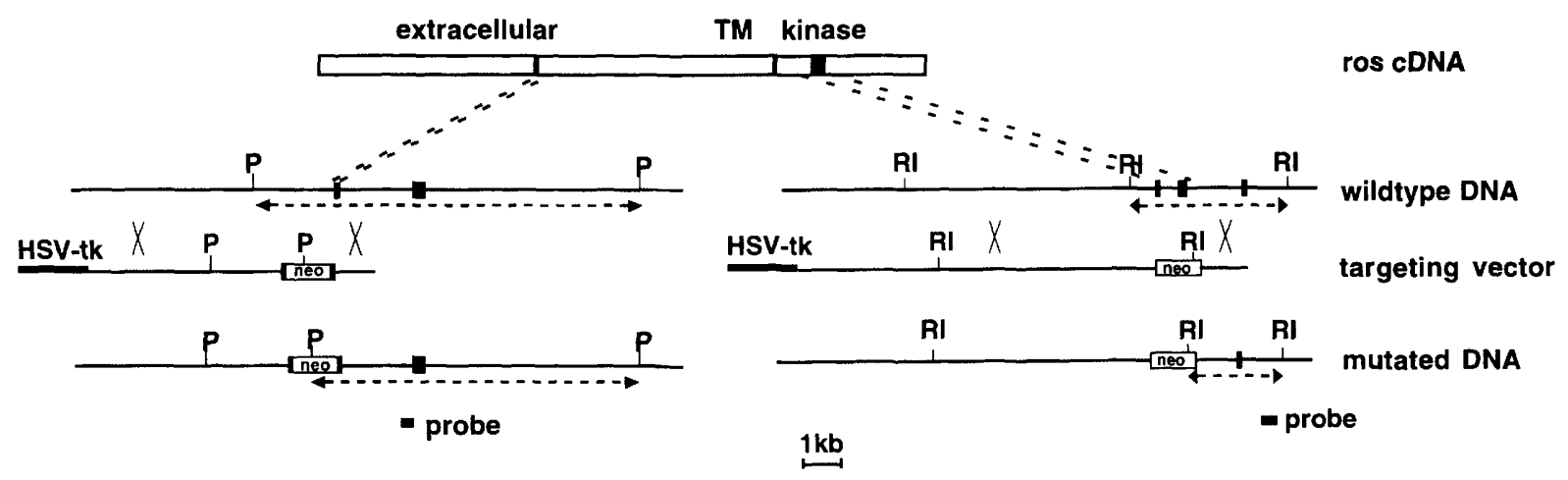

Figure 1. Strategy applied to mutate the murine c-ros locus in the extracellular (left) or the kinase domain (right). The schematic structure of the c-ros receptor is shown at the very top, and extracellular, transmembrane (TM), and cytoplasmically located tyrosinespecific protein kinase domains are indicated. (Below) A schematic representation of the genomic DNA from the wild-type allele (top), the targeting vectors (middle) and the mutated alleles (bottom). Exon sequences are indicated by solid boxes; restriction enzyme sites $[P v u I I(\mathrm{P})$; EcoRI (RI)], the neo cassette, and the HSV-tk gene are indicated. Specific fragments detected by Southern hybridization on wild-type and mutated DNA (shown in Fig. 2a,b) are indicated by broken lines, and the probes used are represented by boxes. 
(a)

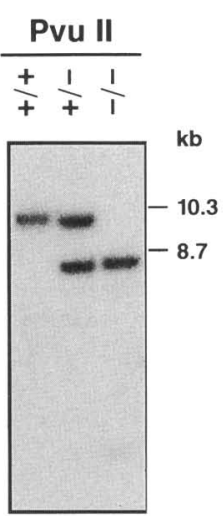

(b)

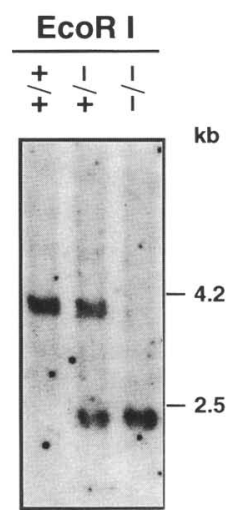

(C)

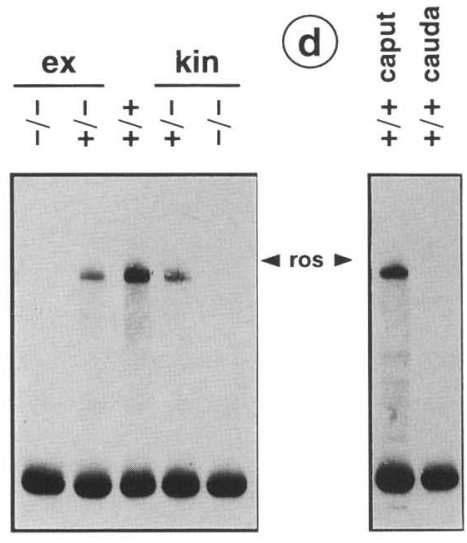

Figure 2. (a) Southern blot analysis of DNA from wild-type $(+1+)$, heterozygous $\operatorname{ros}^{e x}(+1-)$ and homozygous ros ${ }^{e x}(-/-1$ mice digested by PvuII. Wild-type $(10.3 \mathrm{~kb})$ and mutant fragments $(8.7 \mathrm{~kb})$ are indicated. $(b)$ Southern blot analysis of DNA from wild-type $(+1+)$, heterozygous $\operatorname{ros}^{k i n}\left(+1-1\right.$, and homozygous $\operatorname{ros}^{k i n}(-1-)$ mice. Wild-type $(4.2 \mathrm{~kb})$ and mutant fragments $(2.5 \mathrm{~kb})$ are indicated. (c) Western blot analysis on protein extracts from epididymides of homozygous ros ${ }^{e x}$ (ex $-/-$ ), heterozygous ros $^{\text {ex }}$ (ex $+/-$, wild-type $(+1+)$, heterozygous $\operatorname{ros}^{k i n}$ ( $\mathrm{kin}+/-1$, and homozygous $\operatorname{ros}^{k i n}$ (kin $\left.-/-\right)$ animals. $(d)$ Western blot analysis on protein extracts of caput and cauda epididymidis of wild-type animals. The band corresponding to the c-Ros protein is indicated; (below) the heavy chain of the IgG used for precipitation is visible.

taining the entire c-ros coding sequences and the neo cassette; this transcript ends at the poly(A) site of c-ros. When cDNA probes encoding kinase sequences were used, only the $9.2 \cdot \mathrm{kb}$ mutant transcript was observed (Fig. 3A).

The 8-kb transcript of the wild-type mouse c-ros gene encodes a receptor-like protein described previously by us and others (Birchmeier et al. 1990; Sharma et al. 1989; Matsushime and Shibuya 1990; Chen et al. 1991; Zong et al. 1993; Riethmacher et al. 1994). In addition, a smaller sized transcript is produced during spermatogenesis (Matsushime and Shibuya 1990; Sonnenberg et al.
1991; Tessarollo et al. 1992). The testis-specific transcript of the mouse contains coding sequences for transmembrane and cytoplasmic domains; it lacks $3 \mathrm{~kb}$ that encodes the amino terminus of the extracellular domain (Sonnenberg et al. 1991; S. Gödecke and C. Birchmeier, unpubl.). This $5.2-\mathrm{kb}$ transcript is not affected by the mutation present in the DNA of $\operatorname{ros}^{e x}$ mice (Fig 3b). However, the short transcript is nonfunctional, because the c-Ros protein cannot be detected in testis extracts. Nontranslated transcripts of other genes that are expressed during spermatogenesis have been described previously (Delaney et al. 1993; Ivell 1994).

Table 1. Fertility of ros mice

a. Matings of ros heterozygous and ros homozygous mutant mice

\begin{tabular}{|c|c|c|c|c|c|c|}
\hline \multicolumn{2}{|c|}{ Genotype $^{a}$} & \multirow{2}{*}{$\begin{array}{c}\text { Matings } \\
\text { (no. of males) }\end{array}$} & \multirow{2}{*}{$\begin{array}{l}\text { Number of } \\
\text { offspring }\end{array}$} & \multicolumn{3}{|c|}{ Genotype of offspring } \\
\hline males & females & & & $+1+$ & $+1-$ & $-1-$ \\
\hline $\begin{array}{l}+/ \operatorname{ros}^{e x} \\
+/ \operatorname{ros}^{k i n}\end{array}$ & $\begin{array}{l}+/ \operatorname{ros}^{e x} \\
+/ \operatorname{ros}^{k i n}\end{array}$ & $\begin{array}{r}10(6) \\
5(3)\end{array}$ & $\begin{array}{l}65 \\
39\end{array}$ & $\begin{array}{l}13 \\
11\end{array}$ & $\begin{array}{l}36 \\
18\end{array}$ & $\begin{array}{l}16 \\
10\end{array}$ \\
\hline $\begin{array}{l}\operatorname{ros}^{e x} / \operatorname{ros}^{e x} \\
\operatorname{ros}^{k i n} / \operatorname{ros}^{k i n} \\
\operatorname{ros}^{e x} / \operatorname{ros}^{k i n}\end{array}$ & $\begin{array}{l}+1+ \\
+1+ \\
+1+\end{array}$ & $\begin{array}{c}100(30) \\
140(25) \\
20(3)\end{array}$ & $\begin{array}{l}0 \\
0 \\
0\end{array}$ & $\begin{array}{l}0 \\
0 \\
0\end{array}$ & $\begin{array}{l}0 \\
0 \\
0\end{array}$ & $\begin{array}{l}0 \\
0 \\
0\end{array}$ \\
\hline $\begin{array}{l}+/ \operatorname{ros}^{e x} \\
+/ \operatorname{ros}^{k i n}\end{array}$ & $\begin{array}{c}\operatorname{ros}^{e x} / \operatorname{ros}^{e x} \\
\operatorname{ros}^{k i n} / \operatorname{ros}^{k i n}\end{array}$ & $\begin{array}{l}50(25) \\
70(26)\end{array}$ & $\begin{array}{l}355 \\
501\end{array}$ & $\begin{array}{l}0 \\
0\end{array}$ & $\begin{array}{l}180 \\
245\end{array}$ & $\begin{array}{l}175 \\
256\end{array}$ \\
\hline
\end{tabular}

b. Matings of chimeric mice

\begin{tabular}{|c|c|c|c|c|c|c|}
\hline \multicolumn{2}{|c|}{ Genotype $^{b}$} & \multirow{2}{*}{$\begin{array}{c}\text { matings } \\
\text { (no. of males) }\end{array}$} & \multirow{2}{*}{$\begin{array}{l}\text { Number of } \\
\text { offspring }\end{array}$} & \multicolumn{3}{|c|}{ Genotype of offspring } \\
\hline chimera & female & & & $+1+$ & $+/ \operatorname{ros}^{e x}$ & $+/ r_{0} s^{k i n}$ \\
\hline $\operatorname{ros}^{e x} / \operatorname{ros}^{k i n} /+1+$ & $+1+$ & $40(10)$ & 165 & 86 & 42 & 37 \\
\hline
\end{tabular}

${ }^{a}$ Male and female mice with indicated genotypes were mated; the offspring were genotyped by PCR.

${ }^{b}$ Chimeric males were generated as described in Materials and methods and mated with wild-type females. The offspring were genotyped by PCR. 
(a)

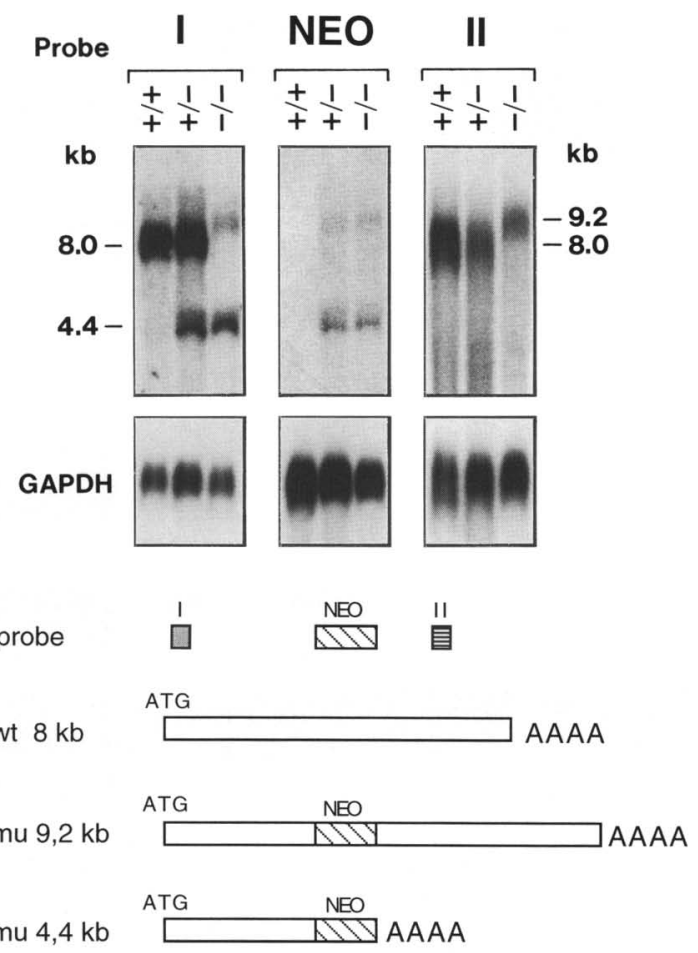

(b)

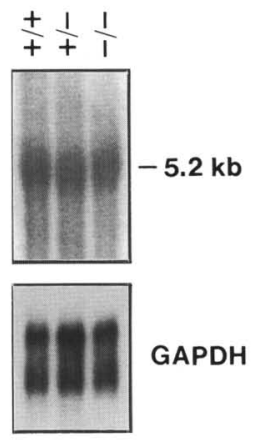

Figure 3. (a) Northern blot analysis of poly $\mid \mathrm{A})^{+}$RNA obtained from intestine dissected from wild-type $(+1+1$, heterozygous $(+1-1$, or homozygous $(-1-)$ mutant embryos; the mutant allele corresponds to $\operatorname{ros}^{e x}$. Ros cDNA encoding extracellular (I) or kinase sequences (II) or sequences from the neo gene (NEO) were used as probes (top). The sizes of the hybridizing transcripts are indicated. For a control, the filters were rehybridized with GADPH sequences (middle). The structure of the various ros transcripts produced by the wild-type and mutant alleles are depicted schematically at bottom. (b) Northern analysis of poly $(\mathrm{A})^{+}$RNA obtained from testis dissected from wild-type $(+1+1$, heterozygous $(+1-)$, or homozygous $(-1-)$ mutant embryos; the mutant allele corresponds to ros ${ }^{e x}$. Ros cDNA encoding kinase sequences were used as a probe $\{t o p \mid$. The size of the testis-specific ros transcript is indicated and is not affected by the mutation, as it starts downstream of the inserted neo sequences. For a control, the filters were rehybridized with GADPH sequences (bottom).
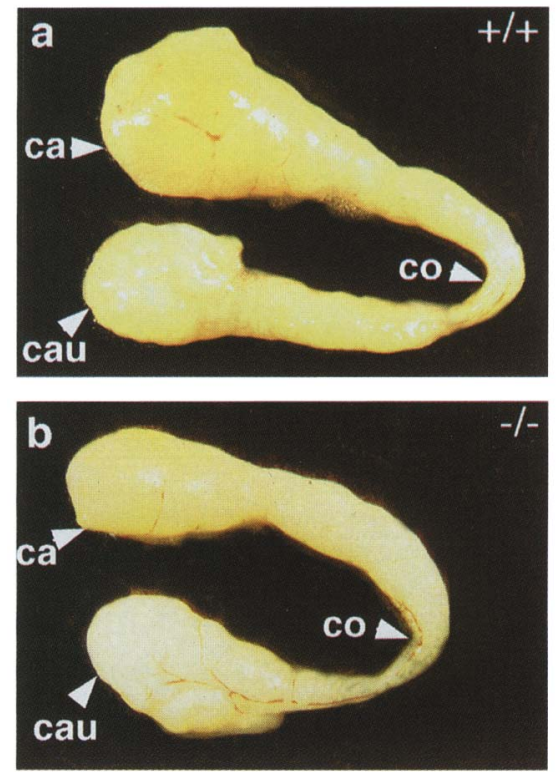

Figure 4. Morphology of an entire epididymis isolated from wild-type $(a)$ or homozygous mutant $(b)$ animals. Note the difference in size of the caput (ca), whereas corpus (co) and cauda (caul appear similar.

\section{Phenotype of the c-ros mutations}

Animals with $\operatorname{ros}^{e x} / \operatorname{ros}^{e x}$ or $\operatorname{ros}^{k i n} / \operatorname{ros}^{k i n}$ genotype are viable and appear healthy. Female homozygous mutant animals display normal fertility. In contrast, male homozygous mutant animals are sterile (Table la). However, they are not impaired in sexual activity, and we now use them routinely to replace vasectomized animals. Normal amounts of sperm are produced in the mutant males, which is evident when the caudal part of the epididymis is analyzed histologically (Fig. 5h,j, below), or if sperm from the caudal part is collected and counted $13 \times 10^{6}$ to $8 \times 10^{6}$ sperm isolated from a single cauda epididymidis of $-1-$ or control animals $/$. The caput epididymidis is clearly aberrant in homozygous mutant males, regardless of whether they carry $\operatorname{ros}^{e x}$ and/or $\operatorname{ros}^{k i n}$ alleles. This is apparent on external examination, because the caput of homozygous mutant animals is reduced in size when compared with the caput of control littermates (Fig. 4a,b). Histological analysis of control $+/-$ or $+/+$ animals reveals the presence of characteristic, tall columnar epithelial cells with long microvilli in the proximal part of the caput, also termed the initial segment (Fig. 5a,c). These tall columnar cells are completely absent in homozygous mutant males (Fig. 5b,d). Instead, distinct low columnar epithelial cells are found in the proximal epididymis from ros - $/$ - animals; in control animals such cells are typical for more distal parts of the caput (Fig. $5 \mathrm{e}-\mathrm{g}$ ).

Previously, expression of c-ros had been detected by in situ hybridization in the embryonal Wolffian duct and one of its derivatives, the embryonal ureter /Sonnenberg 

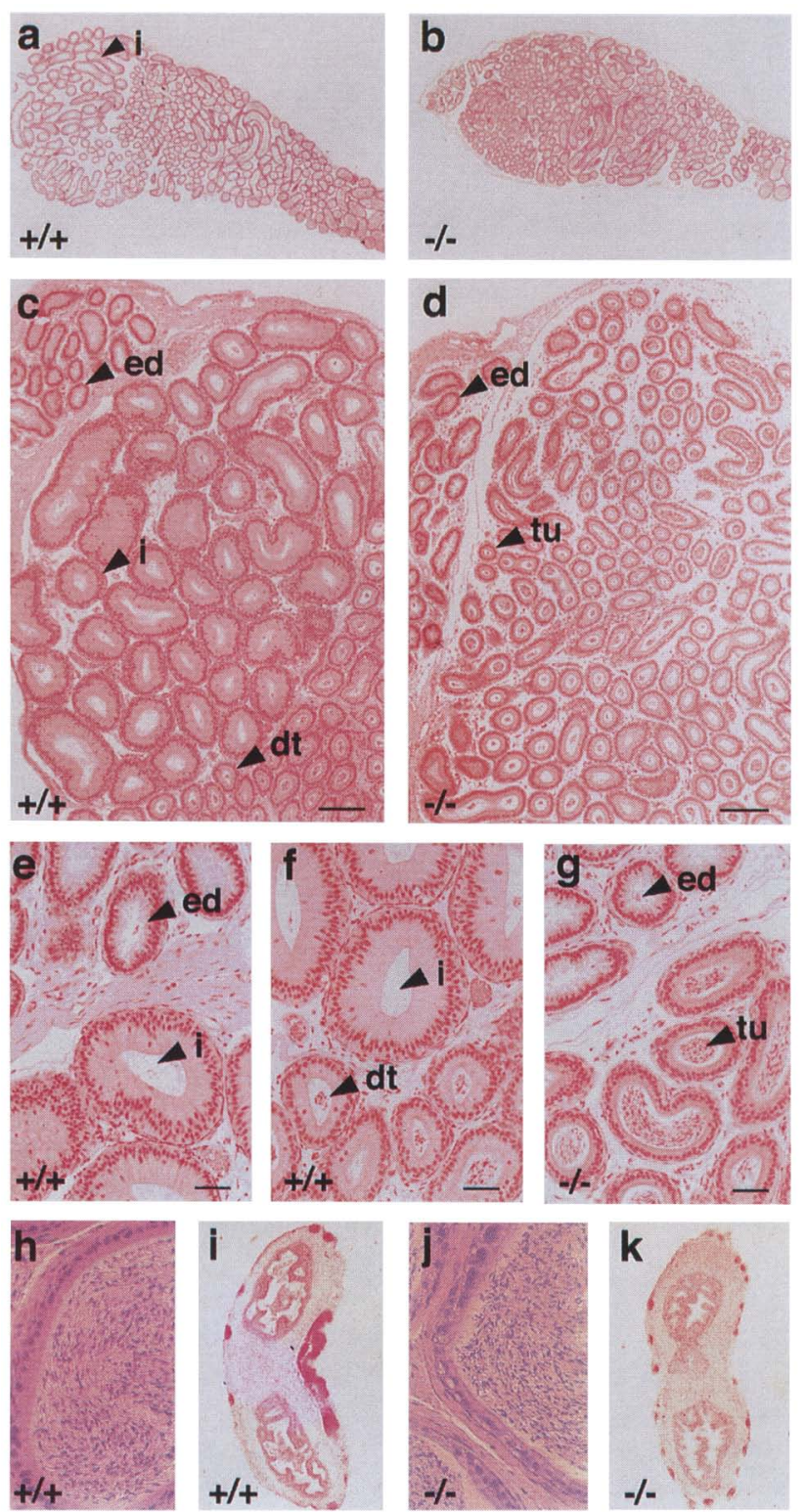

Figure 5. Histological analysis of the caput epididymidis isolated from wild-type $(a, c)$ and homozygous mutant $(b, d)$ animals. Efferent ductules (ed), tubules of the initial segment (i), and distally located tubules $(\mathrm{dt})$ are indicated by arrowheads in sections from wild-type caput epididymidis. Note the absence of tubules formed by high epithelial cells in the proximal segment of the caput epididymidis of homozygous mutant animals. They are replaced by tubules (tu) formed by epithelial cells that resemble in morphology cells of the distal caput epididymidis (dt) in wild-type animals. Higher magnification of sections obtained from wild-type $(e, f)$ and homozygous mutant $(g)$ caput epididymidis with efferent ductules, tubules of the initial and distal segments are shown. The tubules present in the proximal caput epididymidis of mutant animals are indicated. Similar histological appearance of the cauda epididymidis $(h, j)$ and vas deferens $(i, k)$ of a wild-type $(h, i)$ and homozygous mutant $(j, k)$ animals. $(c, d)$ Bars $150 \mu \mathrm{m}_{i}(e-g)$ bars, $50 \mu \mathrm{m}$. et al. 1991; Tessarollo et al. 1992). We have analyzed adult Wolffian duct derivatives for c-ros expression by in situ hybridization and found strong hybridization signals in the epididymis of adult males (Fig. 6a). No specific hybridization signals were detected in the efferent ductules, vas deferens, seminal vesicles, or ampullaestructures that also develop from the Wolffian duct. In these structures, no change was apparent in the homozygous mutant animals (Fig. 5i,k; data not shown). Epididymal expression of c-ros in the adult is specific for epithelial cells, and is confined to caput but not corpus (Fig. 6a) or cauda. This was verified by the analysis of the c-Ros protein, which in control animals was detected only in the caput epididymidis and not the cauda (Fig. 2d).

Within the caput epididymidis, expression of c-ros is not uniform. Regionalization of the caput epididymidis is apparent when the c-ros-specific hybridization signal is analyzed. Cells in the initial segment express high levels of c-ros, and distally located cells of the caput express intermediate levels (Fig. 6). In the caput epididymidis of homozygous mutant males, the initial segment that expresses high levels of transcript is absent but cells that express an intermediate level of c-ros can be observed in animals that carry the ros ${ }^{e x}$ allele (Fig. 6c,d). This signal derives from stable mutant transcripts that are produced from the ros ${ }^{e x}$ allele (Fig. 3a). Within the caput epididymidis, loss of the initial segment that expresses high levels of c-ros correlates with loss of regionalized morphology. The cell type that expresses high levels of c-ros, that is, tall columnar epithelial cells in the initial segment, are not found in homozygous mutant animals. No other histological alterations are found in ros - 1 - animals, and all organs that express c-ros during development-the kidney, intestine, lung, or testisappeared normal in homozygous mutant animals.

We analyzed activity of endogenous $\beta$-galactosidase in epididymal epithelia by staining with X-gal. We had observed previously that $\beta$-galactosidase is expressed in a regionalized manner in control animals; strong staining was observed in the initial segment of the caput epididymidis and in the corpus epididymidis (Fig. $6 \mathrm{~g}$ ). The distal segment of the caput is characterized by the absence of blue color (Fig. 6g). In mutant animals, the initial strongly staining segment is absent (Fig. $6 \mathrm{~h}$ ). The combined histological and expression data demonstrate, therefore, that differentiation and regionalization of the proximal epididymal epithelium is severely altered in mice that lack a functional c-ros gene.

The c-ros receptor is not required in a cell autonomous manner for production and function of sperm

We analyzed the cell autonomy of c-ros function in germ-line cells and tested whether male chimeric animals that contain c-ros $-1-$ and c-ros $+1+$ cells can transmit the mutant and wild-type ros alleles. These chimera were produced by fusion of $r o s^{e x} / r^{k} s^{k i n}$ and wildtype morulae. No preference in the transmission of mu- 

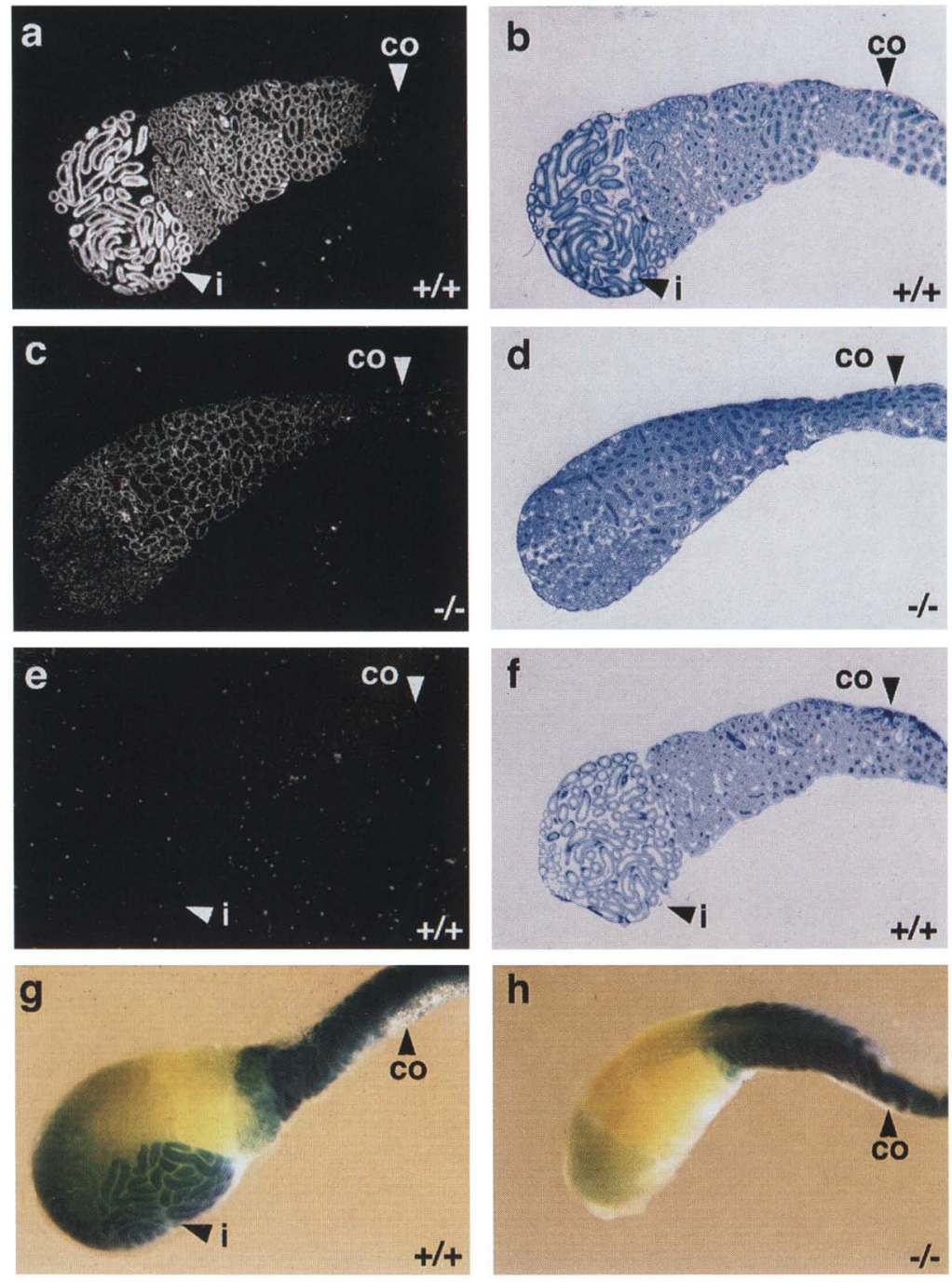

Figure 6. Expression of c-ros in the proximal epididymis of wild-type $(a)$ and homozygous mutant (c) animals, as analyzed by in situ hybridization and observed in dark field; $|b, d|$ appearance of the sections in bright field. Control hybridization with the corresponding sense c-ros probe in dark field $(e)$ and bright field $|f|$. Endogenous $\beta$-galactosidase activity, as visualized by X-gal staining, in the epididymis of wild-type $(g)$ and homozygous mutant $(h)$ animals. tant or wild-type ros alleles was observed (Table 1b). Therefore, c-ros is not required in a cell autonomous manner for sperm production or function.

Sperm from the cauda of $\operatorname{ros}^{e x} / \operatorname{ros}^{e x}$ or $\operatorname{ros}^{k i n} / \operatorname{ros}^{\text {kin }}$ animals was isolated and used for in vitro fertilization of eggs obtained from $\mathrm{C} 57 / \mathrm{Bl} 6$ females. Even at low sperm concentrations $\left(1 \times 10^{5}\right.$ to $\left.3 \times 10^{5} / \mathrm{ml}\right)$, no significant difference in the fertilization efficiency of sperm isolated from mutant or control animals was apparent. Embryos obtained from in vitro fertilizations were able to reach the morula stage in culture. After transfer to the oviduct, they developed and produced healthy animals. In addition, we analyzed for the presence of pre-implantation embryos in vivo. Only unfertilized eggs were present when $\operatorname{ros}^{e x} /$ ros $^{e x}$ or ros ${ }^{k i n} /$ ros $^{\text {kin }}$ male animals were used for matings with females. After mating with control male animals, $80 \%$ of the eggs were fertilized and developed to the morula stage.

Sperm was isolated from the uteri or oviducts of females after mating with c-ros $-/$ - or control males. We could detect similar numbers of sperm $\left(10^{4}-10^{6}\right.$ sperm cells) in the uteri of all females irrespective of the male used for mating. However, sperm counts from the oviduct revealed small differences. We detected $1 \times 10^{3}-$ $6 \times 10^{4}$ sperm cells after matings with control animals. After matings with mutant animals, we found no sperm in a significant proportion of oviducts (10 of 26), and $1 \times 10^{3}-1 \times 10^{4}$ sperm cells in the remainder of the oviducts.

\section{Discussion}

Mice carrying either of two distinct mutant alleles of the c-ros gene ros $^{e x}$ and $\operatorname{ros}^{k i n}$, respectively) were generated using homologous recombination and ES-cell technology. No c-Ros protein can be detected in animals that carry either allele in a homozygous state. The mice appear healthy, and homozygous females are fertile. However, homozygous mutant males do not reproduce. We demonstrate that the c-ros gene is not required in a cell autonomous manner for sperm production or sperm function. This was shown by the analysis of offspring 
produced by male chimeras, which consist of wild-type and $\operatorname{ros}^{k i n} /$ ros $^{e x}$ cells. Such animals transmit mutant or wild-type c-ros alleles to their offspring with no apparent preference. Therefore, precursor germ cells homozygous for the c-ros mutation can produce functional sperm when they are provided with appropriate (wild-type) cells in their environment. Therefore, c-ros function is indirectly required for male fertility and the mutation affects primarily epithelia of the epididymis, and not germ cells.

Transit through the epididymis is known to be essential for sperm maturation (Bedford 1975; Cooper 1995). During transit, sperm become motile and acquire the ability to undergo acrosome reaction and to penetrate the zona pellucida. The molecular events underlying the maturation processes are largely unknown. Modifications of protein composition take place in the sperm on its transit through the epididymis (Jones et al. 1983; Bellve et al. 1993). Post-translational changes and redistribution of surface proteins can be observed (Brown et al. 1983; Lakoski et al. 1988). Additional alterations in nuclear proteins, such as thecins, are observed (Bellve et al. 1990). Therefore, proteins secreted by the epididymis can alter surface proteins by post-translational modification. Epididymal proteins bind also to different regions of the sperm cell surface (Dacheux and Voglmayr 1983; Rifkin and Olson 1985) and can thereby potentially provide signals that are transmitted into the cells.

Sperm from ros $-1-$ males can fertilize eggs in vitro, and the fertilized eggs develop in vitro or in vivo without apparent defects. This demonstrates that sperm cells of homozygous mutant males are able to recognize the egg, undergo normal acrosome reaction, penetrate the zona pellucida, fuse with the egg, and initiate further development. However, sperm of mutant animals is completely unable to fertilize in vivo. Our observation of a lower number of sperm cells in the oviduct after matings with mutant males might indicate a subtle alteration in sperm function, that is, an effect on movement over long distances or in the environment of the female genital tract, alterations in the capacity to find the egg, or in long term survival of sperm cells.

The inability of ros mutant males to reproduce is caused by a defect in regionalized differentiation of epithelial cells in the epididymis. The epididymal epithelium derives from the Wolffian duct. The adult organ consists of convoluted, tightly packed tubules surrounded by supportive tissue. Sperm cells transit the epididymal tubules on the way from the testis to the vas deferens. The epididymis consists of a superior enlarged head (the caput), a central body (the corpus), and an inferior pointed tail (cauda). The epididymal head is connected to the upper testicular pole by efferent ductules, which develop from mesonephric tubules. Different epithelial cell types can be distinguished by morphological criteria: (1) The efferent ductules contain low columnar epithelia, which surround an irregularly shaped lumen; (2) the initial segment of the caput consists of tall columnar epithelia with long microvilli that surround a regularly shaped, small lumen that contains few sperm, only. Other features characteristic of this segment are high expression levels of c-ros and high levels of an endogenous $\beta$-galactosidase activity; (3) distal tubules in the caput contain lower columnar epithelia that surround a small lumen containing sperm, express lower levels of c-ros, and display little or no $\beta$-galactosidase activity; (4) in corpus and cauda the height of the epithelia is even more reduced, $c$-ros expression is absent, $\beta$-galactosidase activity is very high, and the caudal tubules surround large lumen that contain typically large amounts of sperm. We have characterized the changes in the epididymal epithelium of c-ros -1 - animals using histology, analysis of c-ros expression and of endogenous $\beta$-galactosidase activity. We find changes associated with only the initial segment of the caput and all methods of analysis indicate that the initial segment of the caput is not formed in mutant animals. The absence of specific segments of the epididymis could correlate with the absence of specific molecules important in sperm maturation.

Regionalization of the epididymal epithelium is a differentiation process that occurs during puberty. In 16day-old male mice, the epididymis is still small. Terminal differentiation of the epithelia has not occurred yet, and morphologically, all epithelia of the caput are uniform. Our data indicate that c-ros controls regionalization of the epithelium. As a first sign of this regionalization during development, we detected an up-regulation of c-ros expression in the initial segment of the caput cpididymidis. The regionalized differentiation might be induced by an initially uniformly distributed c-ros and an asymmetrical distribution of the ligand whose molecular nature is as yet unknown. The c-ros-mediated signal might then initiate terminal differentiation of the epithelium, and consequently the regionalized expression of various markers, including c-ros. However, a role of c-ros in survival of epididymal cells in the initial but not the more distal segments cannot be excluded. Therefore, our genetic analysis of c-ros provides not only insight into the function of the receptor but reveals also a possible source of the unidentified ligand. Such a ligand could be produced locally, for instance, by mesenchymal cells of the epididymis, and drive growth and differentiation of the epididymis by mesenchymal epithelial interactions (Birchmeier and Birchmeier 1993). Hoxa11 and Hoxa10 have been implicated in regionalization of epithelia that derive from the Wolffian duct. Mutation of the Hoxa11 gene results in transformation of vas deferens into an epididymal-like structure and leads to differences in epithelial differentiation (Hsieh-Li et al. 1995). Transcription factors of the Hox family might therefore control expression of tyrosine kinase receptor and/or of their ligands, which eventually control regionalization and terminal differentiation of the Wolffian duct.

Our data demonstrate an exquisite specificity of c-ros function in development of distinct and few epithelial cells, that affects male physiology in a profound manner. Absence of Ros protein leads to a defect restricted to the initial segment of the epididymis. This in turn results in male sterility, without affecting sperm production. The infertility is attributable to a subtle change in the sperm 
maturation and function. Infertility in man is frequently associated with production of low numbers or of morphologically abnormal sperm. However, in many instances the cause for infertility cannot be determined. It might be of interest to test for the presence of an intact c-ros gene in such individuals.

\section{Materials and methods}

\section{Construction of targeting vectors}

Genomic c-ros DNA was isolated from a C57/B16 or Ola 129 library and used for the construction of a targeting vector to mutate sequences that encode an extracellular $\left(\operatorname{ros}^{e x}\right)$ or a cytoplasmic $\left(r^{k i n}\right)$ domain, respectively. Specifically, the neo cassette (Mansour et al. 1988) was inserted into an exon encoding nucleotides 2962-3370 of the cDNA (see Riethmacher et al. 1994 for the numbering of cDNA and amino acids in murine c-ros) to generate the $\operatorname{ros}^{e x}$ targeting vector; the inserted neo cassette contains stop codons in all three reading frames. To construct the $\operatorname{ros}^{k i n}$ targeting vector, two exons containing nucleotides 6267-6467 were deleted and replaced by the neo cassette. In addition, the thymidine kinase gene from herpes simplex virus (HSV-tk) was included in both targeting vectors for negative selection (Mansour et al. 1988).

\section{Targeting of ES cells and generation of transgenic animals}

E14-1 cells, a subclone of the E14 ES cell line, were used to introduce the targeting vectors by electroporation (Kühn et al. 1991). Targeted ES cells were enriched for by selection with G418 (400 mg/ml) and Gancyclovir $(2 \mathrm{~mm})$ and identified by PCR. Southern blot analyses on ES cell clones with $r^{e x}$ or ros $^{k i n}$ mutation were performed to verify that a single integration event had occurred by homologous recombination. For this, three probes were used: a probe corresponding to cDNA sequences outside the targeting vector (see also Fig. 1), a probe corresponding to DNA sequences present on the targeting vector, and a probe corresponding to sequences of the neo gene (not shown|. Blastocyst injections and identification of chimeras that transmit the c-ros mutation were performed essentially as described (Bradley 1987). Routinely, the genotypes of animals and embryos were identified by PCR and occasionally verified by Southern blot analysis.

\section{In situ hybridization and Northern and Western blot analysis}

Gonads from control or $\operatorname{ros}^{\text {ex }} /$ ros $^{e x}$ mice aged 16 or 21 days, 2 or 18 months, were prepared and embedded either in paraffin or Tissuetek (Miles Inc.). Sectioning and in situ hybridization were performed essentially as described (Sonnenberg et al. 1991). As a probe, RNA-containing nucleotides 1-2245 of murine c-ros was used. Specific signals were observed with an RNA probe in antisense orientation but not with the corresponding sense RNA probe. Northern blot analysis was performed as described (Sonnenberg et al. 1991).

Western blot analysis was carried out as described (Riethmacher et al. 1994). Polyclonal antibodies produced against the 11 carboxy-terminal amino acids of the murine c-Ros protein were generated in rabbits and used for the analysis.

\section{Histological examinations and X-gal staining}

Tissues were fixed in $4 \%$ formaldehyde and embedded in Technovit 7001 (Heraeus Kulzer $\mathrm{GmbH}$ ) as recommended by the manufacturer, and $8-\mu \mathrm{m}$ sections were used for staining with hematoxylin/eosin. X-gal staining was carried out as described (Gossler and Zachgo 1993).

\section{In vitro and in vivo fertilization}

In vitro fertilization was essentially performed as described (Fraser 1993; Hogan 1994). Sperm isolated from cauda epididymidis of control and ros - / - animals was transferred into 1.2 $\mathrm{ml}$ of Whittingham medium in a 5-ml Eppendorf tube and incubated for $45 \mathrm{~min}$ at $37^{\circ} \mathrm{C}$. During this incubation period, sperm capacitation occurs. Sperm concentration in the upper part of the medium $(100-200 \mu l)$ after incubation ranged from $1 \times 10^{5}$ to $8 \times 10^{5}$ sperm cell $/ \mathrm{ml}$ and was used for in vitro fertilization at a concentration of $1 \times 10^{5}$ to $3 \times 10^{5}$ sperm cells $/ \mathrm{ml}$. Eggs, together with cumulus cells, were added and incubated for 4-8 hr, moved to CZB medium (Bleil 1993), and incubated overnight. Embryos had reached the two-cell stage after this treatment and were then transferred into the infundibulum of pseudopregnant foster mothers.

For assessment of in vivo fertilization frequencies, eggs were flushed from oviducts $1,1.5$, and 2.5 days after mating and incubated in M16 medium for up to 2 days. For analysis of sperm numbers in the genital tract of female mice after matings, the presence of genital plugs was tested every hour. One or $4 \mathrm{hr}$ after mating, the uterus and oviduct were flushed with Whittingham medium and sperm numbers were determined in a hemocytometer.

Generation of chimeric mice by morula aggregation

Female mice homozygous for the $\operatorname{ros}^{e x}$-mutation were mated with male mice carrying the $\operatorname{ros}^{k i n}$ allele in the heterozygous state. Morulae from such matings were fused with wild-type morulae essentially as described (Bradley 1987). An equal proportion of chimera that carry rosex $/$ ros $^{k i n}$ cells and $+1+$ cells or, alternatively, $\operatorname{ros}^{e x} /+$ cells and $+/+$ cells, are generated by such a procedure. Male chimeras were analyzed by PCR for the simultaneous presence of both $\operatorname{ros}^{k i n}$ and $\operatorname{ros}^{e x}$ alleles, or for the presence of the ros ${ }^{e x}$ allele only. The presence of mutant alleles in the offspring was determined by PCR.

\section{Acknowledgments}

We thank Drs. Lynn Fraser (King's College, London, UK) and Peter Ekblom (Uppsala University) for advice and helpful discussions, W. Birchmeier (MDC Berlin, Germany), and A. Garratt (MDC Berlin, Germany) for critical reading of the manuscript, Prof. A.F. Holstein (Universität Hamburg, Germany) and Dr. Schulze (Universität zu Köln, Germany) for the electron microscopic analysis of sperm from mutant animals, Dr. A. Aguzzi (Universität Zürich, Switzerland), and Prof. W. Zschiesche (MDC, Berlin, Germany) for advice on histology of the epididymis, U. Ringeisen (Köln) for preparing Figures 1-3, and Michael Tönjes for technical help. We also thank Dirk Meyer for pointing out that endogenous $\beta$-galactosidase is expressed in the epididymis in a segmented pattern. We are particularly grateful for the technical assistance of Andrea Rehaus. A large part of this work was done at the Max-Delbrück-Labor in der Max-Planck-Gesellschaft in Köln. This work was supported by grants from the Max-Planck-Gesellschaft /nicht-öffentliche Mittel), from the Bundesministerium für Bildung und Familie and the Bundesministerium für Forschung und Technologie to C.B.

The publication costs of this article were defrayed in part by 
payment of page charges. This article must therefore be hereby marked "advertisement" in accordance with 18 USC section 1734 solely to indicate this fact.

\section{References}

Bargmann, C.I., M.C. Hung, and R.A. Weinberg. 1986. The neu oncogene encodes an epidermal growth factor receptor-related protein. Nature 319: 226-230.

Bedford, J.M. 1975. Maturation, transport and fate of spermatozoa in the epididymis. In Handbook of physiology (ed. R.O. Greep and E.B. Astwood); Vol. 5, pp. 303-317, American Physiological Society, Washington D.C.

Bellve, A.R., R. Chandrika, and A. Barth. 1990. Temporal expression, polar distribution and transition of an epitope domain in the perniclear theca during mouse spermatogenesis. I. Cell. Sci. 96: 745-756.

Bellve, A.R., W. Zheng, and Y.S. Martinova. 1993. Recovery, capacitation, acrosome reaction and fractionation of sperm. In Guide to techniques in mouse development (ed. P. Wassaman and M.L. DePhamphilis|, Vol. 225, pp. 113-135. Academic Press, San Diego.

Besmer, P., J.E. Murphy, P.C. George, F.H. Qiu, P.J. Bergold, L. Lederman, H.J. Snyder, D. Brodeur, E.E. Zuckerman, and W.D. Hardy. 1986. A new acute transforming feline retrovirus and relationship of its oncogene v-kit with the protein kinase gene family. Nature 320: 415-421.

Birchmeier, C. and W. Birchmeier. 1993. Molecular aspects of mesenchymal-epithelial interactions. Annu. Rev. Cell. Biol. 9: $511-540$.

Birchmeier, C., D. Birnbaum, G. Waitches, O. Fasano, and M. Wigler. 1986. Characterization of an activated human ros gene. Mol. Cell. Biol. 6: 3109-3116.

Birchmeier, C., K. O'Neill, M. Riggs, and M. Wigler. 1990. Characterization of rosl cDNA from a human glioblastoma cell line. Proc. Natl. Acad. Sci. 87: 4799-4803.

Bladt, F., D. Riethmacher, S. Isenmann, A. Aguzzi, and C. Birchmeier. 1995. Essential role for the c-met receptor in the migration of myogenic precursor cells into the limb bud. $\mathrm{Na}$ ture 376: 768-771.

Bleil, Y.D. 1993. In vitro fertilization. In Guide to techniques in mouse development (ed. P. Wassaman and M.L. DePamphilis), Vol. 225, pp. 253-266. Academic Press, San Diego, CA.

Bradley, R. 1987. Production and analysis of chimeric mice. In Teratocarcinoma and embryonic stem cells: A practical approach (ed. D. Rickwood and B.D. Homes), pp. 113-153. IRL Press, Oxford, UK.

Brown, C.R., K.I. von Glos, and R. Jones. 1983. Changes in plasma membrane glycoproteins of rat spermatozoa during maturation in the epididymis. I. Cell. Biol. 96: 256-264.

Chen, J., C.S. Zong, and L.H. Wang. 1994. Tissue and epithelial cell-specific expression of chicken proto-oncogene c-ros in several organs suggests that it may play roles in their development and mature functions. Oncogene 9: 773-780.

Chen, J.M., D. Heller, B. Poon, L. Kang, and L.H. Wang. 1991. The proto-oncogene c-ros codes for a transmembrane tyrosine protein kinase sharing sequence and structural homology with sevenless protein of Drosophila melanogaster. Oncogene 6: 257-264.

Cooper, T.J. 1995. Role of the epididymis in mediating changes in the male gamete during maturation. $A d v$. Exp. Med. Biol. 377: 87-101.

Dacheux, J. and M. Paquignon. 1980. Relations between the fertilizing ability, motility and metabolism of epididymal spermatozoa. Reprod. Nutr. Dev. 20: 1085-1099.
Dacheux, J.L. and J.K. Voglmayr. 1983. Sequence of sperm cell surface differentiation and its relationship to exogenous fluid proteins in the ram epididymis. Biol. Reprod. 29: 10331046.

Delaney, S.J., D.P. Rich, S.A. Thomson, M.R. Hargrave, P.K. Lovelock, M.J. Welsh, and B.J. Wainwright. 1993. Systic fibosis transmembrane conductance regulator splice variants are not conserved and fail to produce chloride channels. $\mathrm{Na}$ ture Genet. 4: 426-431.

Douglass, J., S. Garrett, and J. Garrett. 1991. Differential patterns of regulated gene expression in the adult rat epididymis. Ann. N.Y. Acad. Sci. 637: 384-398.

Dumont, D.J., G. Gradwohl, G.H. Fong, M.C. Puri, M. Gertsenstein, A. Auerbach, and M.L. Breitman. 1994. Dominantnegative and targeted null mutations in the endothelial receptor tyrosine kinase, tek, reveal a critical role in vasculogenesis of the embryo. Genes \& Dev. 8: 1897-1909.

Fraser, L. 1993. In vitro capacitation and fertilization. Methods Enzymol. 225: 239-253.

Geissler, E., M. Ryan, and D. Housman. 1988. The dominant white spotting (W) locus of the mouse encodes the c-kit protooncogene. Cell 55: 185-192.

Gossler, A. and J. Zachgo. 1993. Gene and enhancer trap screens in ES cell chimeras. In Gene targeting: A practical approach |ed. A.L. Joyner|, pp. 200-203. IRL Press, Oxford, UK.

Hampe, A., M. Gobet, C.J. Sherr, and F. Galibert. 1984. Nucleotide sequence of the feline retroviral oncogene $v$-fms shows unexpected homology with oncogenes encoding tyrosinespecific protein kinases. Proc. Natl. Acad. Sci. 81: 85-89.

Hogan, B., R. Beddington, F. Constantini, and E. Lacy. 1994. Manipulating the mouse embryo, Cold Spring Harbor Laboratory Press, Cold Spring Harbor, NY.

Hsieh-Li, H., D. Witte, M. Weinstein, W. Branford, H. Li, K. Small, and S. Potter. 1995. Hoxall structure, extensive antisense transcription and function in male and female fertility. Development 121: 1373-1385.

Ivell, R. 1994. The proopiomelanocortin gene is expressed as both full-length and 5 'truncated transcripts in rodent Leydig cells. Reprod. Fertil. Dev. 6: 791-794.

Jones, R., K.I. von Gloss, and C.R. Brown. 1983. Changes in the protein composition of rat spermatozoa during maturation in the epididymis. I. Reprod. Fertil. 67: 299-306.

Kühn, R., K. Rajewsky, and W. Müller. 1991. Generation and analysis of interleukin-4 deficient mice. Science 254: 707710.

Lakoski, K.A., C.P. Carron, C.L. Cabot, and P.M. Saling. 1988. Epididymal maturation and the acrosome reaction in mouse sperm: Response to zona pellucida develops coincident with modification of M42 antigen. Biol. Reprod. 38: 221-233.

Lu, X., L.A. Perkins, and N. Perrimon. 1993. The torso pathway in Drosophila: A model system to study receptor tyrosine kinase signal transduction. Development (Suppl.) 47-56.

Lunde, T., E. Christiansen, and K. Purvis. 1990. Epididymis. Anatomy, function and pathology. Tidsskr Nor Laegeforen 110: 3119-3123.

Mansour, S.L., K.R. Thomas, and M.R. Capecchi. 1988. Disruption of the proto-oncogene int- 2 in mouse embryo-derived stem cells: a general strategy for targeting mutations to nonselectable genes. Nature 336: 348-352.

Martin, Z.D., S.H. Hughes, and M. Barbacid. 1986. A human oncogene formed by the fusion of truncated tropomyosin and protein tyrosine kinase sequences. Nature 319: 743748.

Matsushime, H. and M. Shibuya. 1990. Tissue-specific expression of rat c-ros- 1 gene and partial structural similarity of its predicted products with sev protein of Drosophila melano- 
gaster. J. Virol. 64: 2117-2125.

Meyer, D. and C. Birchmeier. 1995. Multiple essential functions of neuregulin in development. Nature 378: 386-390.

Miettinen, P.J., J.E. Berger, J. Meneses, Y. Phung, R.A. Pedersen, Z. Werb, and R. Derynck. 1995. Epithelial immaturity and multiorgan failure in mice lacking epidermal growth factor receptor. Nature 376: 337-341.

Neckameyer, W.S. and L.H. Wang. 1985. Nucleotide sequence of avian sarcoma virus UR2 and comparison of its transforming gene with other members of the tyrosine protein kinase oncogene family. $J$. Virol. 53: 879-884.

Neckameyer, W., M. Shibuya, M. Hsu, and L. Wang. 1986. Proto-oncogene c-ros codes for a molecule with structural features common to those of growth factor receptors and displays tissue-specific and developmentally regulated expression. Mol. Cell. Biol. 6: 1478-1486.

Riethmacher, D., O. Langholz, S. Gödecke, M. Sachs, and C. Birchmeier. 1994. Biochemical and functional characterization of the murine ros protooncogene. Oncogene 9: 36173626.

Rifkin, J.M. and G.E. Olson. 1985. Characterization of maturation dependent extrinsic proteins of the rat sperm surface. $l$. Cell Biol. 100: 1582-1591.

Robaire, B. and R. Viger. 1995. Regulation of epididymal epithelial cell functions. Biol. Reprod. 52: 226-236.

Sato, T.N., Y. Tozawa, U. Deutsch, B.K. Wolburg, Y. Fujiwara, M.M. Gendron, T. Gridley, H. Wolburg, W. Risau, and Y. Qin. 1995. Distinct roles of the receptor tyrosine kinases Tie-1 and Tie-2 in blood vessel formation. Nature 376: 7074.

Savant, B.S. and D.J. Montell. 1993. torso-like encodes the localized determinant of Drosophila terminal pattern formation. Genes \& Dev. 7: 2548-2555.

Schmidt, C., F. Bladt, S. Goedecke, V. Brinkmann, W. Zschiesche, M. Sharpe, E. Gherardi, and C. Birchmeier. 1995. Scatter factor/hepatocyte growth factor is essential for liver development. Nature 373: 699-702.

Sharma, S., C. Birchmeier, J. Nikawa, K. O'Neill, L. Rodgers, and M. Wigler. 1989. Characterization of the ros I-gene products expressed in human glioblastoma cell lines. Oncogene Res. 5: 91-100.

Sibilia, M. and E.F. Wagner. 1995. Strain-dependent epithelial defects in mice lacking the EGF receptor. Science 269: 234 238.

Sonnenberg, E., A. Godecke, B. Walter, F. Bladt, and C. Birchmeier. 1991. Transient and locally restricted expression of the ros 1 protooncogene during mouse development. EMBO I. 10: 3693-3702.

Sun, E. and C.J. Flickinger. 1979. Development of cell types and of regional differences in the postnatal rat epididymis. Am. $J$. Anat. 154: 27-56.

Takahashi, M. and G.M. Cooper. 1987. ret transforming gene encodes a fusion protein homologous to tyrosine kinases. Mol. Cell. Biol. 7: 1378-1385.

Tessarollo, L., L. Nagarajan, and L. Parada. 1992. c-ros: The vertebrate homolog of the sevenless tyrosine kinase receptor is tightly regulated during organogenesis in mouse embryonic development. Development 115: 11-20.

Threadgill, D.W., A.A. Dlugosz, L.A. Hansen, T. Tennenbaum, U. Lichti, D. Yee, C. LaMantia, T. Mourton, K. Herrup, R.C. Harris, et al. 1995. Targeted disruption of mouse EGF receptor: Effect of genetic background on mutant phenotype. Science 269: 230-234.

Wang, Z.Q., M.R. Fung, D.P. Barlow, and E.F. Wagner. 1994. Regulation of embryonic growth and lysosomal targeting by the imprinted Igf2/Mpr gene. Nature 372: 464-467.
Winer, M., A. Wadewitz, and D. Wolgemuth. 1993. Members of the raf gene family exhibit ssgment-specific patterns of expression in mouse epididymis. Mol. Rep. Dev. 35: 16-23.

Yamamoto, T., T. Nishida, N. Miyajima, S. Kawai, T. Ooi, and K. Toyoshima. 1983. The erbB gene of avian erythroblastosis virus is a member of the src gene family. Cell 35: 71-78.

Zong, C.S., B. Poon, J. Chen, and L.H. Wang. 1993. Molecular and biochemical bases for activation of the transforming potential of the proto-oncogene c-ros. J. Virol. 67: 6453-6462. 


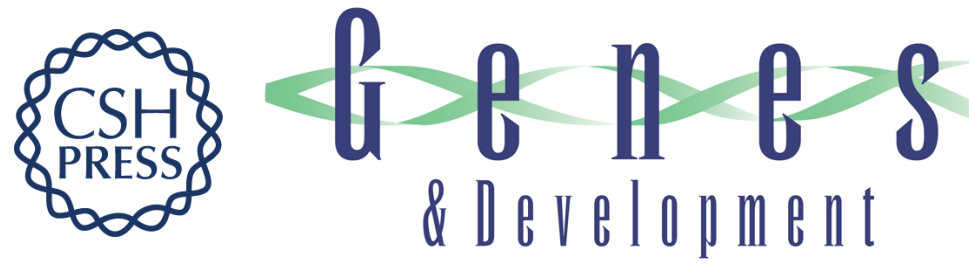

\section{The c-ros tyrosine kinase receptor controls regionalization and differentiation of epithelial cells in the epididymis.}

E Sonnenberg-Riethmacher, B Walter, D Riethmacher, et al.

Genes Dev. 1996, 10:

Access the most recent version at doi:10.1101/gad.10.10.1184

References This article cites 49 articles, 19 of which can be accessed free at:

http://genesdev.cshlp.org/content/10/10/1184.full.html\#ref-list-1

License

Email Alerting

Service

Receive free email alerts when new articles cite this article - sign up in the box at the top right corner of the article or click here.

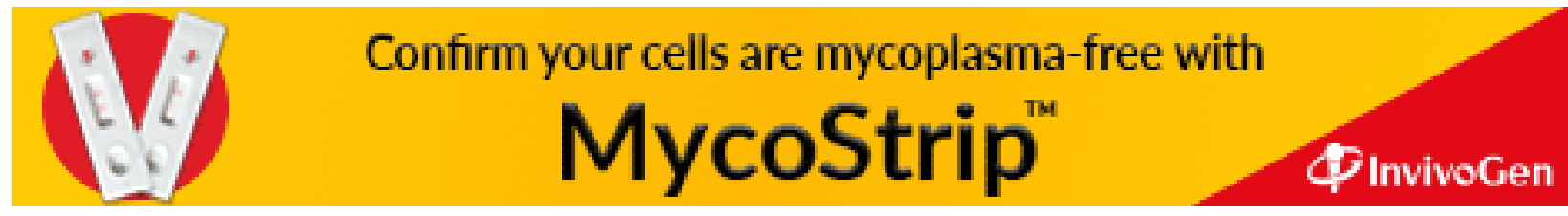

